\title{
Immunoglobulin Heavy Chain Diversity and Joining Region Gene Rearrangement
}

National Cancer Institute

\section{Source}

National Cancer Institute. Immunoglobulin Heavy Chain Diversity and Joining Region Gene

Rearrangement. NCI Thesaurus. Code C124222.

A molecular abnormality indicating the presence of gene rearrangement(s) of the immunog lobulin heavy chain (IGH) locus in the regions encoding the diversity and/or joining regions. 